\title{
Weed strip management for minimizing soil erosion and enhancing productivity in the sloping lands of north-eastern India
}

\author{
Narendra Kumar Lenka ${ }^{a, *}$, K.K. Satapathy ${ }^{a}$, Rattan Lal ${ }^{b}$, R.K. Singh ${ }^{a}$, N.A.K. Singh ${ }^{a}$, P.K. Agrawal , \\ P. Choudhury ${ }^{\mathrm{a}}$, A. Rathore ${ }^{\mathrm{d}}$

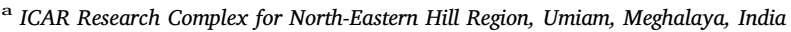 \\ b Ohio State University, Columbus, OH, USA \\ ${ }^{c}$ Indian Council of Agricultural Research, New Delhi, India \\ ' International Crops Research Institute for the Semi-Arid Tropics, Patancheru, Hyderabad, India
}

\section{A R T I C L E I N F O}

\section{Keywords:}

Sloping land technology

Soil conservation

Soil cover management

\begin{abstract}
A B S T R A C T
Soil erosion and shifting cultivation are the major constraints to agriculture in the north-eastern region of India. Low acceptance of cost-intensive soil conservation technologies (e.g., terracing) calls for developing low-cost erosion control measures. Thus, a field experiment was conducted during the monsoon period of 2008 and 2009 , in runoff plots on a land slope of $40 \%$ to test the hypothesis that weed cover, if properly managed, minimizes soil erosion and improves soil productivity. The treatments implemented in duplicates were: maize (Zea mays) under shifting cultivation $\left(\mathrm{T}_{1}\right)$, maize on contour lines $\left(\mathrm{T}_{2}\right)$, groundnut (Arachis hypogea) on upper and maize on lower half of treatment plot, with both on contour lines $\left(\mathrm{T}_{3}\right)$, groundnut on contour lines $\left(\mathrm{T}_{4}\right)$ and maize on contour lines with natural vegetation as buffer strips $\left(\mathrm{T}_{5}\right)$. The average sediment concentration of runoff water varied from $5.20 \mathrm{~g} \mathrm{~L}^{-1}\left(\mathrm{~T}_{1}\right)$ to $1.07 \mathrm{~g} \mathrm{~L}^{-1}\left(\mathrm{~T}_{5}\right)$ in 2008 and from $3.84\left(\mathrm{~T}_{1}\right)$ to $0.89 \mathrm{~g} \mathrm{~L}^{-1}\left(\mathrm{~T}_{5}\right)$ in 2009 . The soil loss ranged from $20.8\left(\mathrm{~T}_{1}\right)$ to $4.7 \mathrm{Mg} \mathrm{ha}^{-1}\left(\mathrm{~T}_{5}\right)$, with corresponding loss of $670-147 \mathrm{~kg} \mathrm{ha}^{-1}$ of $\mathrm{SOC}$, $6.85-1.48 \mathrm{~kg} \mathrm{ha}^{-1}$ of available $\mathrm{N}$, and $2.14-0.87 \mathrm{~kg} \mathrm{ha}^{-1}$ of available P. Weed strips and weed mulch on the upstream side of maize rows in $\mathrm{T}_{5}$ led to formation of stable mini-terraces promoting better plant and root growth. This study indicates cover management involving selective weed retention can reduce soil erosion, favourably modify land slope and promotes soil productivity.
\end{abstract}

\section{Introduction}

Soils, apart from being a medium for plant growth, provide numerous ecosystem services (Keesstra et al., 2016), contribute to mitigating climate change effects and ensuring a healthy environment. Healthy soils with optimum soil functions are vital for sustaining food production and ensuring food and nutrition security to mankind. Soils, being the largest terrestrial carbon pool, play a critical role in sequestering atmospheric carbon and contribute to mitigating greenhouse gas emissions. However, soil erosion leading to a decline in land quality is a major global issue adversely affecting sustainable agricultural productivity (Lal, 2001; Keesstra et al., 2016; Biddoccu et al., 2016). The role of soil erosion is increasingly becoming important due to the intricate relationship between land degradation and global food security (Gessesse et al., 2015; Keesstra et al., 2016). In India, about $45 \%$ of the land area is under various forms of land degradation (Lenka et al., 2012a), with severe water erosion in the high rainfall hilly regions. As per the 2011 Indian census, the north-eastern region of
India with a geographical area of 26.2 million ha, has a population of 44 million. The region accounts for $3.65 \%$ of the total population of the country as against a land share of $7.9 \%$. About $72 \%$ of the land area in the region is hilly (Das et al., 2009). Out of the total land area, $28 \%$ has an altitude higher than $1200 \mathrm{~m}$ and $18 \%$ between 600 and $1200 \mathrm{~m}$ above mean sea level (Das et al., 2009). Being one of the most ecologically-sensitive and challenging regions of the country, it is prone to severe soil erosion, loss of fertile top soil and environmental degradation due to hilly terrain and prevailing shifting cultivation (slash and burn agriculture) practices (Singh et al., 2012; Das et al., 2014; Nath et al., 2016).

Shifting cultivation, locally known as Jhum cultivation, is the major form of agriculture in this region. It is an ecologically viable system of agriculture provided that the fallow cycles (replenishment phase) are long enough to maintain soil fertility and expectations of productivity are not high. However, increasing population pressure has reduced the duration of the fallow phase from 15 to 20 years to 3 to 4 years, causing significant decline in crop yield and soil fertility. Repeated use of land

\footnotetext{
* Corresponding author. Present address: Indian Institute of Soil Science, Nabibagh, Bhopal, India

E-mail addresses: nklenka@rediffmail.com, nklenka74@gmail.com (N.K. Lenka).
} 


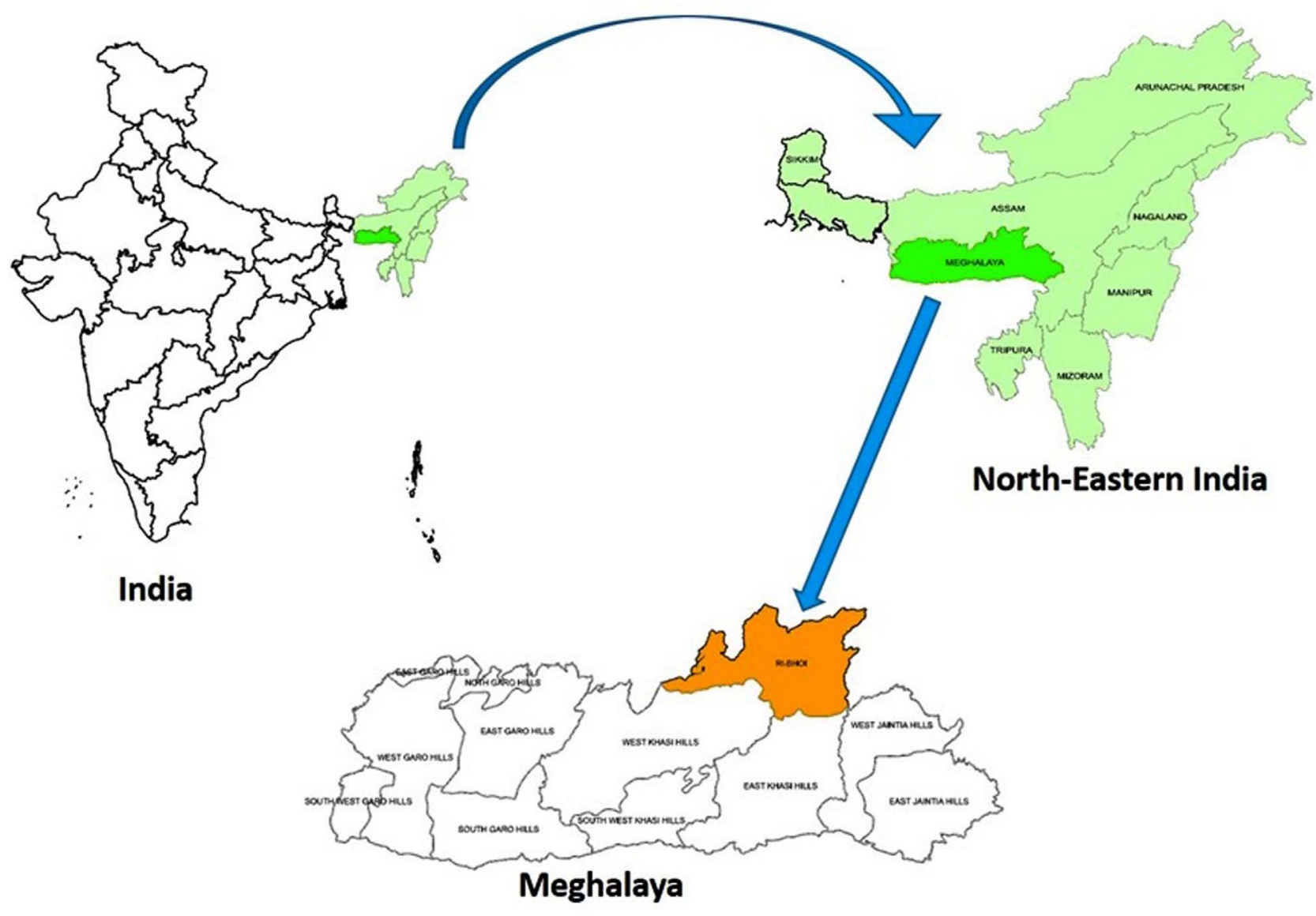

Fig. 1. Location of the study site.

with a short replenishment phase converts the shifting cultivation fallows into degraded wastelands (Lenka et al., 2012a). This requires the farmers to clear new forest areas, aggravating the loss of forest and biodiversity and creating a vicious cycle of deforestation- environmental degradation-low crop yield-poverty-more deforestation. About $80 \%$ of the area of the region is affected by moderate to severe erosion (Velayutham, 1999; Singh et al., 2012). About $59 \mathrm{Mg} \mathrm{ha}^{-1} \mathrm{yr}^{-1}$ of soil erosion has been reported from land with a slope gradient of $45 \%$ (Sharma and Prasad, 1995; Sharma et al., 2014; Sharma and Sharma, 2005) and $170 \mathrm{Mg} \mathrm{ha}^{-1}$ from a slope of $70 \%$ (Singh and Singh, 1978). About 88.3 million tonnes of soil and about 0.5 million tonnes of plant nutrients are lost every year from the region through erosion (Sharma and Prasad, 1995).

Because of the predominantly hilly terrain, a small proportion of the cultivated lands is flat or has a low elevation gradient. These lands are situated near the valleys and are owned by richer members of the community. Thus, most of the agriculture activities are done on sloping lands. Cultivation in the hills and lands situated in the hill slopes is beset with two key problems. First, accelerated soil erosion is severe in the entire north-eastern region. Rainfall received in the region is $>$ $2000 \mathrm{~mm}$ per annum, and is accompanied with torrential storms during the monsoon season (Das et al., 2014). The combined action of torrential rains during the monsoon months and the steep slope gradient results in washing away of the fertile soil and applied inputs including seeds. Secondly, walking up the slope for routine agricultural practices becomes difficult particularly during wet months.

Predominant crops in the shifting cultivation region of north-eastern India are rice (Oryza sativa L.), maize (Zea mays), potato (Solanum tuberosum) and ginger (Zingiber officinales). A modified method of shifting cultivation, known as Bun cultivation, is practised particularly in the Shillong plateau region, where crops are grown 'along the slope' on raised beds. These beds are formed by excavating the soil from both sides and the subsoil layers and leaving narrow channels between two beds for safe disposal of water. Because of the higher level of soil manipulation, this method is more devastating than the traditional shifting cultivation method in terms of soil erosion (Singh et al., 2012). About 0.39 million ha of the 2.28 million ha area of the Shillong plateau region is managed by shifting cultivation, and as much as $76.6 \mathrm{Mg} \mathrm{ha}^{-1}$ $\mathrm{yr}^{-1}$ of soil is lost under this system of farming (Satapathy, 1996).

Depending upon slope gradient, erosion control on arable lands is attempted through biological measures such as live barriers of grasses and hedges (Dass et al., 2011; Lenka et al., 2012b), surface cover of standing crops or crop residues (Lenka et al., 2012a; Das et al., 2014; Biddoccu et al., 2016; Cerdà et al., 2016) and through modification of land configuration and conservation tillage practices (Kuotsu et al., 2014; Ghosh et al., 2015). In a long-term runoff monitoring study in Italy, grass cover reduced runoff by at least $37 \%$ and soil loss was 10 times lower as compared to reduced tillage (Biddoccu et al., 2016). For highway embankment erosion control, Bakr et al. (2015) demonstrated the efficacy of surface mulch through a rainfall simulation experiment. In their experiment, the cumulative runoff loss as a percentage of the applied rainfall reduced from $90 \%$ for the tilled plot to $28 \%$ in treatments having $10 \mathrm{~cm}$ compost/mulch. In any case, the principle is to reduce the runoff velocity and in the long run to alter the land configuration suitably so as to reduce the slope gradient. Terracing, recommended as the best land management system for agriculture on sloping lands, is often not accepted by farmers due to high initial investment. Further, most of the sloping lands are either community lands or owned by small and marginal farmers. Thus, terracing is economically unfeasible.

Alternatively, judiciously managed natural vegetation in accord with specific crop growth stages, serves both as cover and buffer strip. 
Most of the research involving conservation treatments in the remote parts of the country has been limited to flat or gently sloping lands in the valleys (Das et al., 2014; Kuotsu et al., 2014). To date, no study has been conducted in the region to compare the effectiveness of conservation measures on sloping lands. Thus, this study was undertaken to compare the effect of selected cover management techniques vis-a-vis the shifting cultivation in terms of soil and nutrient loss and crop productivity with the hypothesis that manipulating the crop and vegetation cover can moderate slope gradient, reduce soil and nutrient losses, and improve crop productivity.

\section{Materials and methods}

\subsection{Study site}

The field experiment was conducted at the Research Complex of the Indian Council of Agricultural Research (ICAR) for the North-Eastern Hill (NEH) region, Umiam, Meghalaya (Fig. 1). The study site comes under the mid-tropical hill zone ecoregion and is located at $25^{\circ} 41^{\prime} 21^{\prime \prime}$ North latitude and $91^{\circ} 55^{\prime} 25^{\prime \prime}$ East longitude, and at an altitude of $1010 \mathrm{~m}$ above sea level. Average annual rainfall received at the study site is $2390 \mathrm{~mm}$ with a coefficient of variation of $16 \%$. Of this, $80 \%$ is received between the 17th to 42nd meteorological weeks (last week of April to 2nd week of October). The mean monthly maximum temperature ranges from $10.6{ }^{\circ} \mathrm{C}$ (during December) to $27.4{ }^{\circ} \mathrm{C}$ (during August) and mean monthly minimum temperature ranges from $6.5^{\circ} \mathrm{C}$ (during January) to $20.8^{\circ} \mathrm{C}$ (during July). Relative humidity varies between 75 and $83 \%$ during most of the year. Soils of the study area are classified as Typic Paleudalfs with loam to clay loam texture and $\mathrm{pH}$ of 5.4-6.2. The area used for the experiment was under fallow for the five years prior to the study.

\subsection{Experimental treatments}

The experiment was conducted for two consecutive crop years during 2008 and 2009 in runoff plots with different surface cover treatments. The treatments taken in duplicates were: maize (Zea mays) under shifting cultivation $\left(\mathrm{T}_{1}\right)$, maize sown on contour lines $\left(\mathrm{T}_{2}\right)$, ground nut (Arachis hypogea) on upper and maize on lower half of treatment plot, with both sown on contour lines $\left(\mathrm{T}_{3}\right)$, groundnut on contour $\left(\mathrm{T}_{4}\right)$ and maize on contour lines with weed cover as buffer strips $\left(T_{5}\right)$. Maize was planted for the first time in the 1 st year of the experiment after five years of fallow. A total of 10 runoff plots were laid out on land with a slope gradient of $40 \%$. The dimensions of each plot were $22.0 \mathrm{~m}$ long and $1.85 \mathrm{~m}$ wide. The width of each plot was chosen keeping in view the fact that in hilly regions with land slopes of more than $40 \%$, establishing experimental plots at the same location and same aspect is difficult. Two adjacent plots were separated by inserting high density polyethylene (HDPE) sheets. These sheets were inserted $30 \mathrm{~cm}$ below and $30 \mathrm{~cm}$ above ground on all four sides to prevent seepage flow and lateral movement of water from one plot to another (Plate 1). The farmers' practice of shifting cultivation, i.e. Bun method $\left(\mathrm{T}_{1}\right)$ involved four bunds, each with $10.5 \mathrm{~m}$ length, $0.7 \mathrm{~m}$ width and $0.4 \mathrm{~m}$ height above the soil surface. Two bunds were made on the upper portion of the treatment plot and two were on the lower portion. These bunds were prepared up and down the slope at an inter-channel distance of $0.5 \mathrm{~m}$. For the treatment involving weed retention $\left(\mathrm{T}_{5}\right)$, $20-\mathrm{cm}$ weed-free strips were prepared across the slope at $60 \mathrm{~cm}$ intervals. Maize was seeded on the $20-\mathrm{cm}$ weed-free strips after loosening the soil. Weeds were allowed to grow in the inter-strip space for up to 20 days after sowing (DAS), after which manual weeding was done and the weed biomass was spread close to the upstream side of the base of the maize plants. After the first weeding at 20 DAS, two more manual weedings were done at 40 and 60 DAS and the weed biomass was retained on the soil surface as mulch near the upstream side at the base of the maize plants (Fig. 2). This treatment was designed to

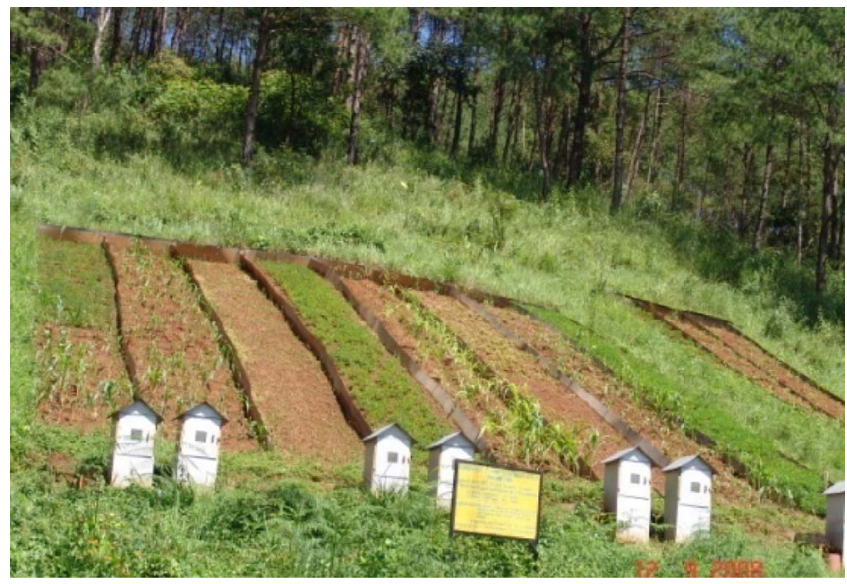

Plate 1. Runoff plots and segregation of runoff plots through High Density Poly Ethylene sheets.

minimize the risks of severe erosion by intense rain storms which are common features of this region during the rainy season.

\subsection{Crop management}

As test crops, maize (cv. Vijaya composite) and groundnut (Arachis hypogaea L.) (cv. ICGS - 76) were sown following the treatment details as mentioned above at a row spacing of $60 \mathrm{~cm}$ and $30 \mathrm{~cm}$, respectively and at plant - plant spacing of $15 \mathrm{~cm}$ for both the crops. In the 2008 season, crops were sown on 08th July and harvested on 01st September. In the 2009 crop season, maize was sown on 13th May, groundnut on 20th May and both crops were harvested on 05th September. The recommended agronomic practices including the rate of fertilizer, plant to plant spacing and weeding were followed in all the treatments. As tillage on such high slopes is difficult, hence, maize and groundnut were planted after pulverizing the top of $10 \mathrm{~cm}$ soil with small farm tools, as practiced by local farmers.

\subsection{Observations taken}

Baseline soil properties were determined before initiation of the experiment following standard methodologies (Table 1). The soil samples in nine replicates were analysed for soil $\mathrm{pH}$ (1:2.5 soil to water suspension using a $\mathrm{pH}$ meter), soil organic carbon (SOC) content by Walkley and Black method, $\mathrm{KMnO}_{4}$ oxidizable $\mathrm{N}$ as plant available $\mathrm{N}$, available P (Bray - I method) and available K content (using $1.0 \mathrm{~N}$ $\mathrm{NH}_{4}$ acetate extractant) following Jackson (1973). During the growing period, measurements were made for soil penetration resistance, runoff, soil loss and nutrient loss as measured in terms of sediment and nutrient concentration of runoff water. Soil penetration resistance (SPR) was measured using a hand held cone penetrometer (Eijelkamp) during different crop growth stages for $0-10 \mathrm{~cm}$ depth. The SPR measurements were made at near field capacity moisture conditions. Nine penetrometer readings were taken from each plot with three each from the lower, middle and top portions of the treatment plots. The nine readings of a plot were averaged to represent a particular treatment.

\subsection{Plant and root biomass at harvest}

Biomass and grain yields of maize and groundnut were recorded at harvest by oven drying at $65^{\circ} \mathrm{C}$ for $48 \mathrm{~h}$. Root weight and root length were measured at harvest and only for maize crop by extraction of soil cores of $10 \mathrm{~cm}$ diameter and $13 \mathrm{~cm}$ height from near the maize plant. From each plot, six root samples were collected with two each in the upper portion, middle and lower portion of the treatment plot. Root samples were carefully cleaned with gentle shaking in small trays filled with water and then primary and secondary roots were separated. The 


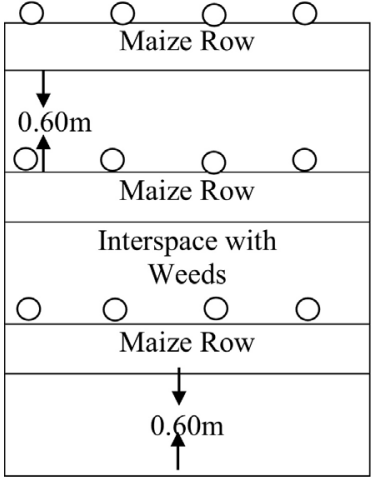

(At time of sowing)

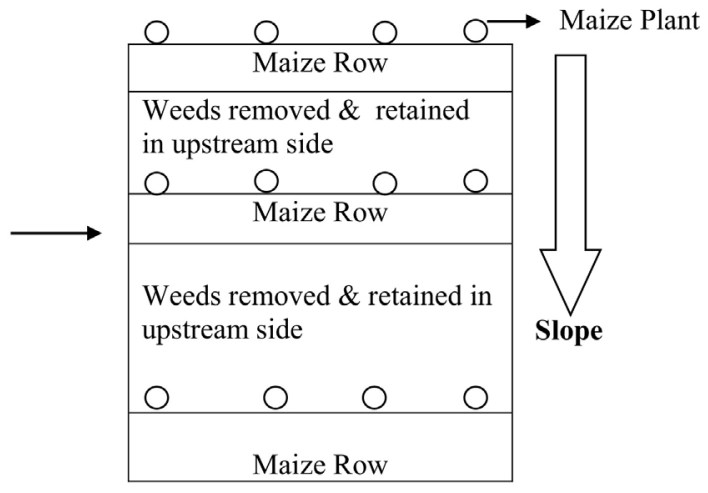

(Weeds removed \& Incorporated after 20, 40 and $60 \mathrm{DAS}$ )

Fig. 2. Schematic illustration of the cover management treatment involving retention and management of natural vegetation for reducing the soil erosion risks.

Table 1

Initial soil properties of the experimental site in the $0-15$ and $15-30 \mathrm{~cm}$ soil layers.

\begin{tabular}{|c|c|c|c|}
\hline Soil property & $0-15 \mathrm{~cm}$ & $15-30 \mathrm{~cm}$ & Methodology used \\
\hline Soil pH (1:2.5) & ${ }^{\mathrm{a}} 5.44 \pm 0.44$ & $5.46 \pm 0.41$ & $\begin{array}{l}\text { 1:2.5soil: water } \\
\text { suspension, } \mathrm{pH} \text { meter }\end{array}$ \\
\hline $\begin{array}{l}\text { Organic carbon } \\
\qquad\left(\mathrm{g} \mathrm{kg}^{-1}\right)\end{array}$ & $26.2 \pm 3.2$ & $20.6 \pm 2.8$ & $\begin{array}{l}\text { Walkley and Black } \\
\text { method }\end{array}$ \\
\hline $\begin{array}{l}\text { Available } \mathrm{N} \\
\qquad\left(\mathrm{kg} \mathrm{ha}^{-1}\right)\end{array}$ & $335.5 \pm 38.8$ & $285.4 \pm 22.6$ & $\begin{array}{l}\mathrm{KMnO}_{4} \text { oxidizable } \\
\text { (Jackson, 1973) }\end{array}$ \\
\hline $\begin{array}{l}\text { Available P } \\
\qquad\left(\mathrm{kg} \mathrm{ha}^{-1}\right)\end{array}$ & $16.5 \pm 2.4$ & $13.6 \pm 1.0$ & Bray - I \\
\hline $\begin{array}{l}\text { Available K } \\
\qquad\left(\mathrm{kg} \mathrm{ha}^{-1}\right)\end{array}$ & $214.1 \pm 10.2$ & $207.9 \pm 7.8$ & $\begin{array}{l}\mathrm{NH}_{4} \text { acetate extractant } \\
\text { (Jackson, 1973) }\end{array}$ \\
\hline
\end{tabular}

${ }^{\text {a }}$ Values are mean \pm standard deviation based on nine replicate measurements.

root length of the freshly collected root samples was measured directly by laying out each piece of root on a graph paper. The root length density, i.e., the length of roots per unit volume of soil, was computed by taking the ratio of measured root length to the volume of soil core used for root sampling (soil volume in this case was $1020 \mathrm{~cm}^{3}$ ). The oven dry root weight was obtained by drying the root samples in a hot air oven at $65^{\circ} \mathrm{C}$ for $48 \mathrm{~h}$.

\subsection{Maize equivalent yield (MEY)}

The crop yield in the treatments was expressed in terms of maize equivalent yield (MEY). The MEY was computed by considering the minimum support price fixed by the Government of India for maize and groundnut crops for the years of study and as per the following formula:

$M E Y=\frac{\text { Priceofgroundnut }}{\text { Priceofmaize }} \times$ Grainyieldofgroundnut $($ quinatals $/ \mathrm{ha})$

\subsection{Measurement of runoff and sediment concentration of runoff water}

The daily rainfall data were collected from the Meteorological Observatory installed by the India Meteorological Department (IMD), using a standard rain gauge, located about $500 \mathrm{~m}$ from the experimental plot. Triangular weirs were installed towards the downstream side of each runoff plot for measuring the runoff generated from each plot. The runoff generated was collected in containers placed in a trench beneath the flume. One container of 5001 capacity was connected at the rim to another container of the same capacity. Although the station regularly receives heavy rains, very high intensity rain storms causing spill over were not recorded during the experimental period. Sediment concentration of runoff water was measured during the experimental period on days receiving rainfall of $>12.5$ $\mathrm{mm}$.

The runoff water collected in the container was thoroughly stirred, and one litre of sample was collected from the middle of the container for determining the sediment concentration of runoff water. The runoff sample was allowed to settle and the clear supernatant liquid was decanted. The remaining suspension was transferred to a glass petridish, and dried in a hot air oven at $65^{\circ} \mathrm{C}$ till a constant weight. The measured sediment concentration of runoff water was expressed in grams per litre $\left(\mathrm{g} \mathrm{L}^{-1}\right)$ and the soil loss in each event was computed from sediment concentration and the runoff volume. The sediment samples collected during the entire crop season were mixed, dried in a hot air oven at $65{ }^{\circ} \mathrm{C}$ and ground to pass through a $2.0 \mathrm{~mm}$ sieve. Moisture correction was made by drying a portion of the sediment sample at $105^{\circ} \mathrm{C}$ for $48 \mathrm{~h}$. The sediment samples were analysed for soil organic carbon (SOC) content (Walkley and Black method), $\mathrm{KMnO}_{4}$ oxidizable or available $\mathrm{N}$, available $\mathrm{P}$ (Bray - I method) and available $\mathrm{K}$ content (using $\mathrm{NH}_{4}$ acetate extractant) following Jackson (1973).

\subsection{Statistical analysis}

For yield and root growth related traits, combined analysis of variance (ANOVA) across two years were performed to test the significance of year $(\mathrm{Y})$, treatment $(\mathrm{T})$ and Year $\times$ Treatment $(\mathrm{YT})$ using SAS MIXED procedure (SAS V9.4). Residual variances of individual year were modelled into combined analysis. Year wise analysis of variance was also performed to test the significance of treatments. Least square means and multiple comparisons for treatments were also estimated. For sediment and nutrient loss through runoff, year wise analysis of variance was performed using general linear model (SAS GLM Procedure) (SAS V9.4) and the least square means and multiple comparison tests for treatments were estimated.

\section{Results}

\subsection{Sediment concentration in runoff samples}

The event wise rainfall and sediment concentration data during the experiment period of 2008 and 2009 crop years are shown as Fig. 3A and $\mathrm{B}$, respectively. The number of runoff events in 2008 was lower than those in 2009. A total of 19 and 21 runoff events (with $\geq 12.5 \mathrm{~mm}$ rainfall per day) were observed in the first and second crop year, respectively. The sediment concentration averaged over all the cover management treatments was $3.28 \mathrm{~g} \mathrm{~L}^{-1}$ in the first year as compared to $2.66 \mathrm{~g} \mathrm{~L}^{-1}$ in the 2 nd crop year. The higher sediment concentration in the 1 st year might be due to higher soil disturbance in the 1st year for the initial land preparation.

For all rainfall events, sediment concentration was significantly 

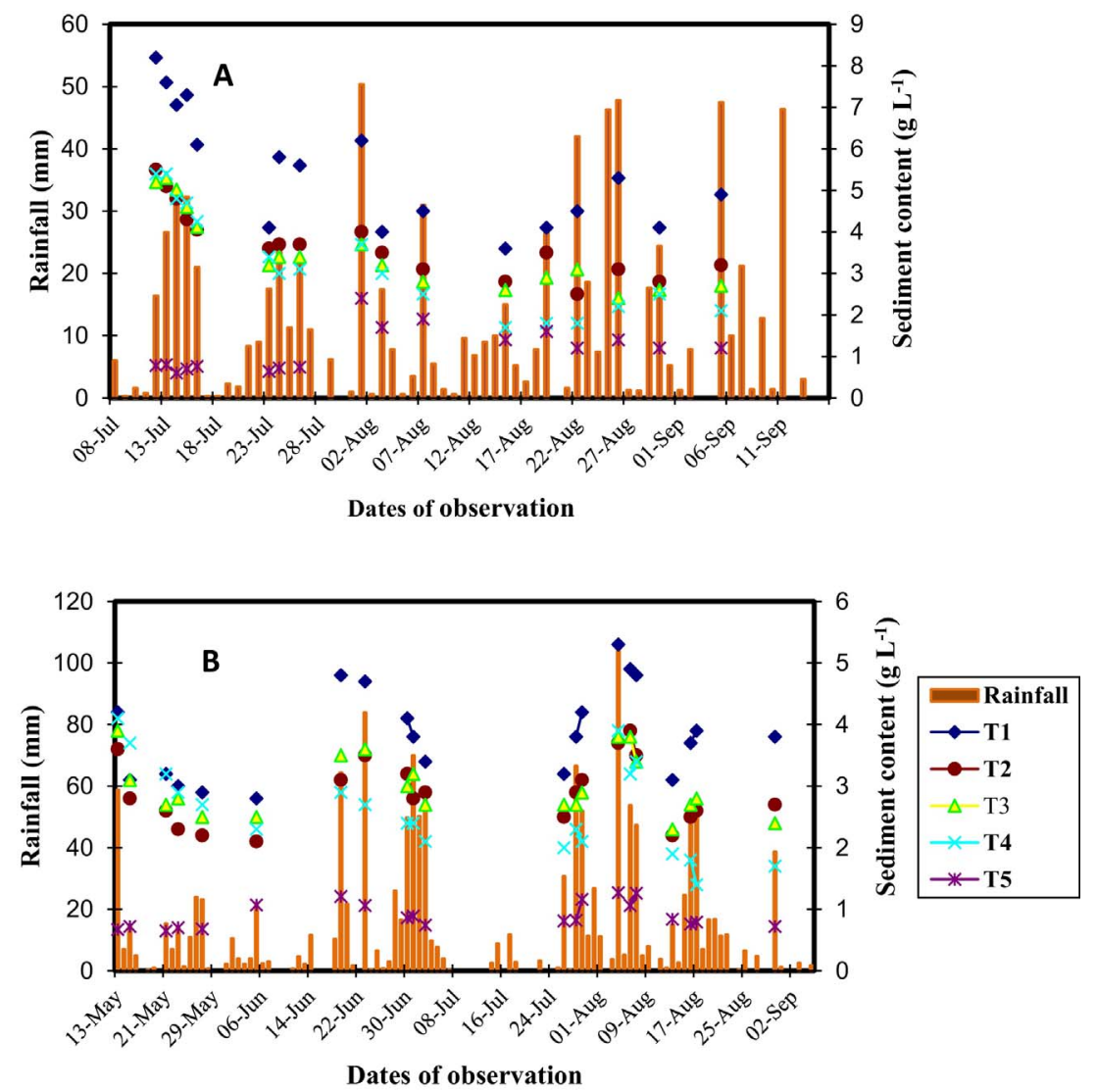

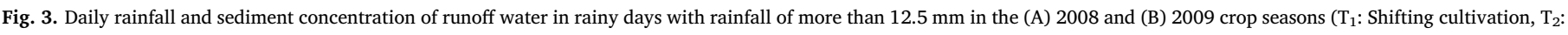
Maize on contour, $\mathrm{T}_{3}$ : Ground nut on upper and maize on lower half, $\mathrm{T}_{4}$ : Groundnut on contour, $\mathrm{T}_{5}$ : Maize on contour with weed cover).

higher under $\mathrm{T}_{1}$ than for other cover management treatments in both the study years (Fig. 4). Significantly lower sediment concentration was observed under $\mathrm{T}_{5}$ treatment. The sediment concentration ranged from $5.20 \mathrm{~g} \mathrm{~L}^{-1}$ under $\mathrm{T}_{1}$ to $1.07 \mathrm{~g} \mathrm{~L}^{-1}$ under $\mathrm{T}_{5}$ (Fig. 3A) during the first year compared with $3.84 \mathrm{~g} \mathrm{~L}^{-1}$ under $\mathrm{T}_{1}$ to $0.89 \mathrm{~g} \mathrm{~L}^{-1}$ under $\mathrm{T}_{5}$ for the second year (Fig. 3B). Despite the difference between the treatments, the magnitude of sediment concentration was also a function of the total amount of rainfall for the event. The multiple pair wise comparison test indicated the sediment concentration to be in the order of $\mathrm{T}_{1}>\mathrm{T}_{2} \approx \mathrm{T}_{3}>\mathrm{T}_{4}>\mathrm{T}_{5}$ in both crop years (Fig. 4). The sediment concentration in the $\mathrm{T}_{1}$ treatment was 3.8 times higher than that for the best treatment $\left(T_{5}\right)$ in the first and 3.3 times in the second crop year.

\subsection{Soil and nutrient loss}

The soil and nutrient loss data averaged over the two years' experiment period is shown in Table 3. Significantly higher loss of soil and nutrients was observed under $\mathrm{T}_{1}$ followed by other treatments and significantly lower soil and nutrient losses were observed in the $T_{5}$ treatment (Tables 2 and 3). The soil loss ranged from $20.8 \mathrm{Mg} \mathrm{ha}^{-1}\left(\mathrm{~T}_{1}\right)$ to $4.7 \mathrm{Mg} \mathrm{ha}^{-1}\left(\mathrm{~T}_{5}\right)$, with corresponding losses of $147-670 \mathrm{~kg} \mathrm{ha}^{-1}$ of SOC, $6.85-1.48 \mathrm{~kg} \mathrm{ha}^{-1}$ of available N, $2.14-0.87 \mathrm{~kg} \mathrm{ha}^{-1}$ of available $\mathrm{P}$ and 7.91-1.71 kg ha ${ }^{-1}$ of available $\mathrm{K}$. The treatments were in the order of $\mathrm{T}_{1}>\mathrm{T}_{2} \approx \mathrm{T}_{4}>\mathrm{T}_{3}>\mathrm{T}_{5}$ in terms of soil and nutrient loss. The combined ANOVA over the two years of experiment showed nonsignificant interaction effect of year and treatment in case of available $P$ and available $\mathrm{K}$ loss (Table 2) whereas the effect was significant for soil loss, SOC and available N loss $(\mathrm{P}<0.05)$. Thus, the soil conservation efficacy of the $T_{5}$ (weed retention) treatment was significantly higher than that of the $\mathrm{T}_{3}$ (upper half maize and lower half groundnut) treatment followed by $\mathrm{T}_{2}$ (maize on contour) and/or $\mathrm{T}_{4}$ (groundnut cover) treatment.

\subsection{Formation of terraces across the slope}

Over time, the growing of crops across the slope led to formation of mini-terraces $\sim 35 \mathrm{~cm}$ wide (Plate 2). However, terraces were formed only in plots with maize as the test crop but not in those under groundnut. Secondly, the number of stable terraces was the highest in $\mathrm{T}_{5}$, having maize with weed retention treatment (Table 4). The number of stable terraces ranged from 9 in $\mathrm{T}_{3}$ to 12 in $\mathrm{T}_{2}$ and 26 in $\mathrm{T}_{5}$ treatment.

\subsection{Soil penetration resistance}

Soil penetration resistance (SPR) measured at different days after sowing indicated significantly $(\mathrm{p}=0.01)$ lower values under $\mathrm{T}_{1}$ than in other treatments during both years of study (Table 2, Fig. 5). The SPR in the $T_{1}$ treatment gradually increased due to settling of soil as observed from higher values in the later dates of measurements and in the 2nd year of study. The SPR values ranged from $0.30 \mathrm{MPa}$ under $\mathrm{T}_{1}$ to $1.93 \mathrm{MPa}$ under $\mathrm{T}_{5}$ treatment at the first measurement date in the $1 \mathrm{st}$ crop season. On an average, the SPR was relatively higher under $\mathrm{T}_{2}$ in both the crop years. Averaged over measurement dates of the 1st crop year, the SPR value in the $\mathrm{T}_{1}$ treatment was lower by 3.1-3.4 times as compared to the average values under other treatments. In the 2nd crop year, the $\mathrm{T}_{1}$ treatment was lower by $2.0-2.3$ times. Though the SPR values in the $T_{2}$ treatment were relatively higher than $T_{3}, T_{4}$ and $T_{5}$ treatments but all the treatments except $\mathrm{T}_{1}$ were statistically at par with one another.

\subsection{Root growth parameters}

The cover management treatments showed a significant effect (Table 2) on the root weight of maize in both years (Table 5, Plate 3). The combined ANOVA indicated the main effects of both 'year' and 
Year: 2008
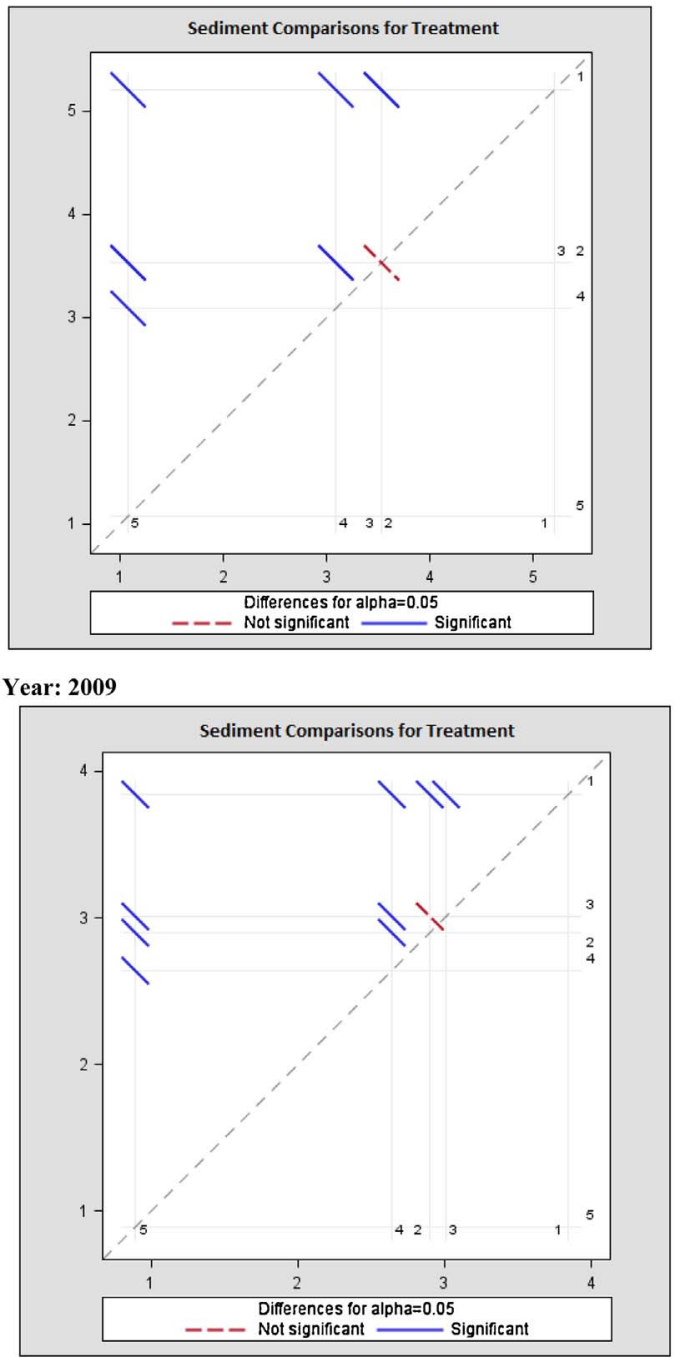

In the above Diffograms, $\mathrm{X}$ and $\mathrm{Y}$ axis represents mean values of 5 treatments $(1,2,3,4$ and 5$)$. Significant difference between any two treatment means is represented with blue color line and nonsignificant difference by red color line.

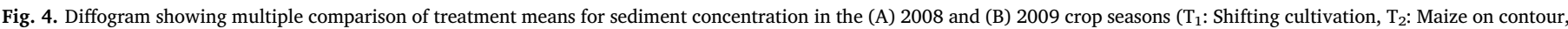
$\mathrm{T}_{3}$ : Ground nut on upper and maize on lower half, $\mathrm{T}_{4}$ : Groundnut on contour, $\mathrm{T}_{5}$ : Maize on contour with weed cover).

Table 2

Significance of differences of Least Square Means between 'Year' and 'Treatments'.

\begin{tabular}{|c|c|c|c|c|c|c|c|c|c|}
\hline Factor & Root weight & RLD & MEY & Soil loss & SPR & SOC loss & Available N loss & Available P loss & Available K loss \\
\hline Year & $*$ & NS & NS & * & * & * & $*$ & NS & NS \\
\hline T1-T2 & $* *$ & $* *$ & $* *$ & $* *$ & $* *$ & $* *$ & $* *$ & $*$ & $* *$ \\
\hline T1-T3 & NS & $*$ & $* *$ & $* *$ & $* *$ & $* *$ & $* *$ & * & $* *$ \\
\hline T1-T4 & - & - & ** & $* *$ & $* *$ & $* *$ & $* *$ & $* *$ & $* *$ \\
\hline T1-T5 & $* *$ & $* *$ & $* *$ & $* *$ & $* *$ & $* *$ & $* *$ & ** & $* *$ \\
\hline T2-T3 & $*$ & NS & $*$ & $* *$ & NS & * & $*$ & NS & $*$ \\
\hline $\mathrm{T} 2-\mathrm{T} 4$ & - & - & $* *$ & NS & NS & NS & NS & NS & NS \\
\hline T2-T5 & $* *$ & $* *$ & $*$ & $* *$ & NS & $*$ & $* *$ & $*$ & $* *$ \\
\hline T3-T4 & - & - & $*$ & $*$ & NS & * & $*$ & NS & NS \\
\hline T3-T5 & $* *$ & $* *$ & NS & $* *$ & NS & $* *$ & $* *$ & $*$ & $*$ \\
\hline T4-T5 & - & - & NS & $* *$ & NS & $*$ & $* *$ & * & $* *$ \\
\hline
\end{tabular}

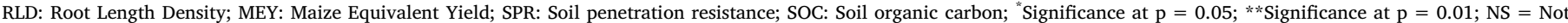
significant; $\mathrm{T}_{1}$ : Shifting cultivation, $\mathrm{T}_{2}$ : Maize on contour, $\mathrm{T}_{3}$ : Ground nut on upper and maize on lower half, $\mathrm{T}_{4}$ : Groundnut on contour, $\mathrm{T}_{5}$ : Maize on contour with weed cover. 
Table 3

Effect of conservation treatments on soil and nutrient loss (average of two years).

\begin{tabular}{|c|c|c|c|c|c|}
\hline \multirow[t]{2}{*}{ Treatment } & \multirow{2}{*}{$\begin{array}{l}\text { Soil loss } \\
\left(\mathrm{Mg} \mathrm{ha}^{-1} \mathrm{yr}^{-1}\right)\end{array}$} & \multicolumn{4}{|c|}{ Nutrient loss $\left(\mathrm{kg} \mathrm{ha}^{-1} \mathrm{yr}^{-1}\right)$} \\
\hline & & Organic carbon & Available N & Available P & Available K \\
\hline $\mathrm{T} 1$ & ${ }^{\mathrm{a}} 20.8 \pm 3.2$ & $670 \pm 52$ & $6.85 \pm 2.14$ & $2.14 \pm 0.86$ & $7.91 \pm 2.04$ \\
\hline $\mathrm{T} 2$ & $11.2 \pm 1.6$ & $345 \pm 47$ & $3.71 \pm 1.44$ & $1.75 \pm 0.71$ & $4.17 \pm 1.63$ \\
\hline T3 & $8.3 \pm 2.6$ & $292 \pm 45$ & $3.04 \pm 0.82$ & $1.54 \pm 0.52$ & $2.98 \pm 0.54$ \\
\hline $\mathrm{T} 4$ & $10.9 \pm 1.2$ & $400 \pm 55$ & $3.78 \pm 1.10$ & $1.52 \pm 0.68$ & $3.62 \pm 0.88$ \\
\hline T5 & $4.7 \pm 1.5$ & $147 \pm 33$ & $1.48 \pm 0.76$ & $0.87 \pm 0.54$ & $1.71 \pm 0.72$ \\
\hline
\end{tabular}

$\mathrm{T}_{1}$ : Shifting cultivation, $\mathrm{T}_{2}$ : Maize on contour, $\mathrm{T}_{3}$ : Ground nut on upper and maize on lower half, $\mathrm{T}_{4}$ : Groundnut on contour, $\mathrm{T}_{5}$ : Maize on contour with weed cover.

a Values are mean \pm standard deviation.
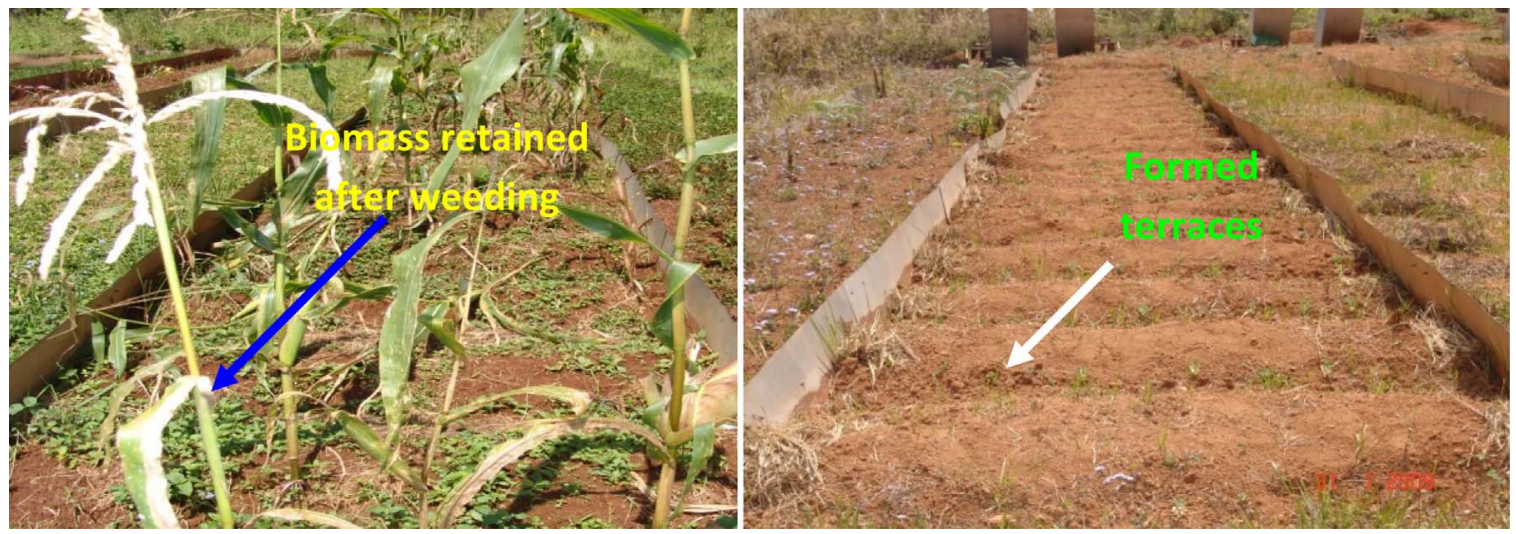

Plate 2. Conservation treatment of contour sowing with retention of weed biomass resulting in formation of mini-terraces.

Table 4

Effect of cover management treatments on modification of land slope as assessed through formation of mini-terraces.

\begin{tabular}{llllll}
\hline \multirow{2}{*}{ Treatment } & \multicolumn{2}{l}{ After 1st crop season } & & \multicolumn{2}{l}{ After 2nd crop season } \\
\cline { 2 - 3 } \cline { 5 - 6 } & Total terraces & Stable terraces\# & & Total terraces & Stable terraces \\
\cline { 5 - 6 } & - & - & - & - \\
T1 & 15 & 12 & 15 & 15 \\
T2 & 12 & 9 & 15 & 11 \\
T3 & - & - & - & - \\
T4 & 28 & 26 & 30 & 28 \\
T5 & & & & \\
\hline
\end{tabular}

\#Stable terraces of $35 \mathrm{~cm}$ width

$\mathrm{T}_{1}$ : Shifting cultivation, $\mathrm{T}_{2}$ : Maize on contour, $\mathrm{T}_{3}$ : Ground nut on upper and maize on lower half, $\mathrm{T}_{4}$ : Groundnut on contour, $\mathrm{T}_{5}$ : Maize on contour with weed cover.

'treatment' to be significant at the $5 \%$ level of significance. Root growth in the 2nd crop year was significantly higher because of a better root growth environment in the form of levelled terraces. The root weight varied from $1.96 \mathrm{~g}$ plant $^{-1}$ under $\mathrm{T}_{1}$ to $7.57 \mathrm{~g}$ plant $^{-1}$ under $\mathrm{T}_{5}$ in the first crop year, and from $2.24 \mathrm{~g}$ plant $^{-1}$ to $8.85 \mathrm{~g} \mathrm{plant}^{-1}$ under the same treatments in the 2nd crop year (Table 5). In both the years, the root weight was significantly higher in $\mathrm{T}_{5}$ as compared to other treatments, with the lowest being under $\mathrm{T}_{1}$. The poor root growth of maize under $\mathrm{T}_{1}$ was attributed to severe erosion caused by a loose soil structure and lower soil strength as indicated by low SPR values under the bun method of cultivation. Across the two study years, the root weight under $T_{5}$ was about 3.8 times higher than that under the $T_{1}$ treatment.

\subsection{Root length density (RLD)}

The root length density (RLD) ranged from 0.36 under $T_{1}$ to $1.08 \mathrm{~cm} \mathrm{~cm}^{-3}$ under the $T_{5}$ treatment during the first year compared with 0.39 and $1.28 \mathrm{~cm} \mathrm{~cm}^{-3}$, respectively, for the second (Table 5). Over the two study years, RLD under $\mathrm{T}_{5}$ was $3.0-3.3$ times higher than
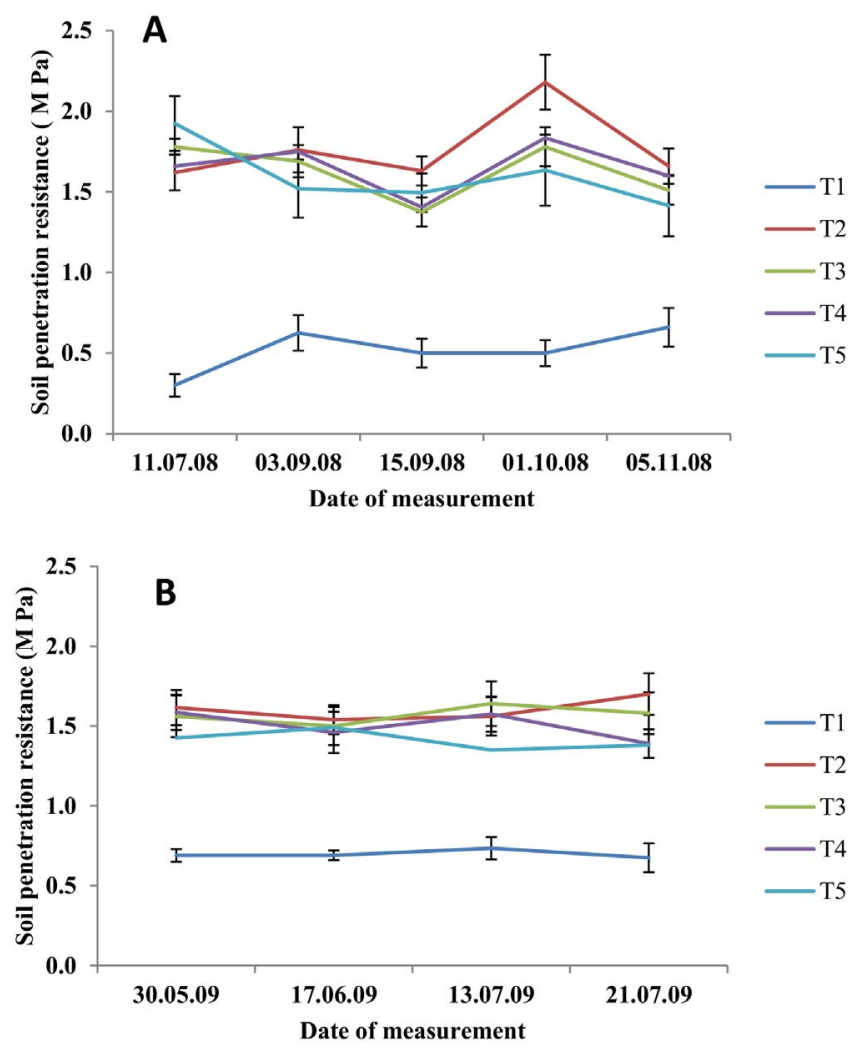

Fig. 5. Soil penetration resistance under different treatments at different measurement dates in the (A) 2008 and (B) 2009 crop seasons $\left(\mathrm{T}_{1}\right.$ : Shifting cultivation, $\mathrm{T}_{2}$ : Maize on contour, $T_{3}$ : Ground nut on upper and maize on lower half, $T_{4}$ : Groundnut on contour, $T_{5}$ : Maize on contour with weed cover). 
Table 5

Effect of soil cover management on maize root growth and maize equivalent yield.

\begin{tabular}{|c|c|c|c|c|c|c|}
\hline \multirow[t]{2}{*}{ Treatments } & \multicolumn{2}{|c|}{ Oven dry root weight (g/plant) } & \multicolumn{2}{|c|}{ Root length density $\left(\mathrm{cm} / \mathrm{cm}^{3}\right)$} & \multicolumn{2}{|c|}{ Maize equivalent yield (Quintals/ha) } \\
\hline & Year - I & Year - II & Year - I & Year - II & Year - I & Year - II \\
\hline $\mathrm{T} 1$ & ${ }^{\mathrm{a}} 1.96 \pm 0.29$ & $2.24 \pm 0.21$ & $0.36 \pm 0.05$ & $0.39 \pm 0.06$ & $6.22 \pm 0.66$ & $8.85 \pm 1.04$ \\
\hline $\mathrm{T} 2$ & $3.47 \pm 0.22$ & $4.04 \pm 0.34$ & $0.74 \pm 0.04$ & $0.74 \pm 0.05$ & $14.5 \pm 0.75$ & $15.05 \pm 2.11$ \\
\hline $\mathrm{T} 3$ & $2.58 \pm 0.30$ & $3.12 \pm 0.24$ & $0.56 \pm 0.06$ & $0.65 \pm 0.04$ & $16.7 \pm 0.94$ & $18.45 \pm 2.14$ \\
\hline T4 & - & - & - & - & $20.35 \pm 2.12$ & $20.38 \pm 1.56$ \\
\hline T5 & $7.61 \pm 0.51$ & $8.85 \pm 0.62$ & $1.08 \pm 0.06$ & $1.28 \pm 0.04$ & $16.71 \pm 1.74$ & $18.83 \pm 2.02$ \\
\hline
\end{tabular}

$\mathrm{T}_{1}$ : Shifting cultivation, $\mathrm{T}_{2}$ : Maize on contour, $\mathrm{T}_{3}$ : Ground nut on upper and maize on lower half, $\mathrm{T}_{4}$ : Groundnut on contour, $\mathrm{T}_{5}$ : Maize on contour with weed cover.

${ }^{\text {a }}$ Values are mean \pm standard deviation.

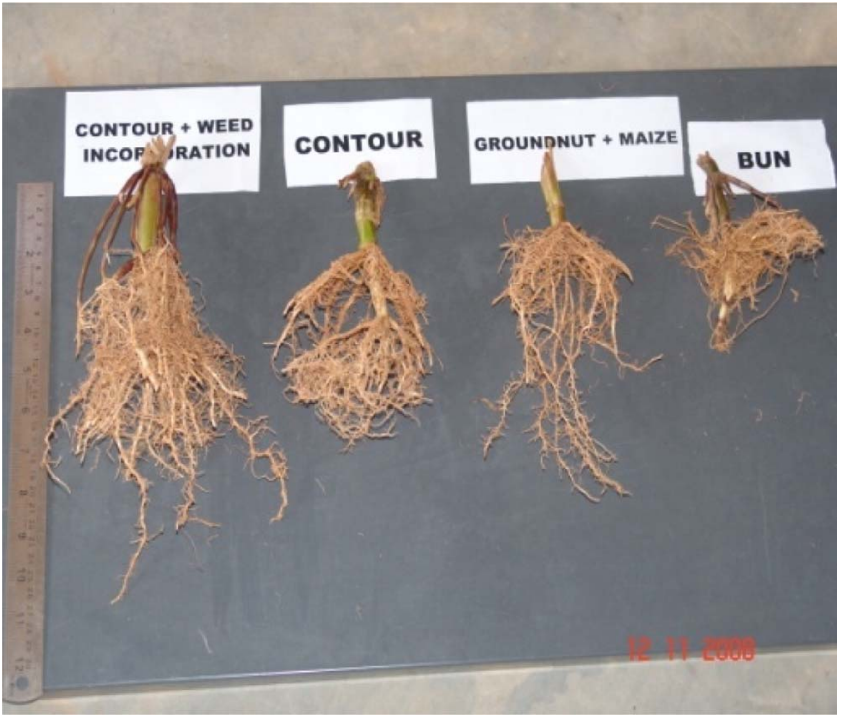

Plate 3. Maize plant roots under specific cover management treatments.

that for the $T_{1}$ treatment. The combined ANOVA (Table 2) showed a significant effect of cover management treatments. However, the effects of year $(P=0.21)$ and the year $\times$ treatment interaction were nonsignificant $(P=0.60)$. Across both seasons, RLD was significantly higher for $\mathrm{T}_{5}$ and significantly lower under $\mathrm{T}_{1}$ than other treatments (Table 2). However, RLD under $\mathrm{T}_{2}$ and $\mathrm{T}_{3}$ were statistically at par with one another.

\subsection{Maize equivalent yield}

The maize equivalent yield (MEY) ranged from 0.62 under $\mathrm{T}_{1}$ to $2.04 \mathrm{Mg} \mathrm{ha}{ }^{-1}$ under $\mathrm{T}_{4}$ treatment in the first year compared with 0.89 and $2.04 \mathrm{Mg} \mathrm{ha}^{-1}$, respectively in the 2nd (Table 5). Across the years, the MEY ranged from $0.75 \mathrm{Mg} \mathrm{ha}^{-1}$ under $\mathrm{T}_{1}$ to $2.04 \mathrm{Mg} \mathrm{ha}^{-1}$ under $\mathrm{T}_{4}$. The highest MEY under the $\mathrm{T}_{4}$ treatment was due to a higher minimum support price of groundnut as compared to maize and also due to a better performance of groundnut on the sloping lands of the region. The difference of least square means from the combined ANOVA indicated $\mathrm{T}_{4}$ and $\mathrm{T}_{5}$ to be statistically at par with one another $(\mathrm{P}=0.051)$. The combined ANOVA (Table 2) showed a significant effect of cover management treatments $(P<0.0001)$. However, the effects of year $(\mathrm{P}=0.08)$ and the year $\times$ treatment interaction were non-significant $(P=0.75)$, indicating similar trend of differences between treatments in both years. Across both years, the MEY under $\mathrm{T}_{4}$ was 2.3-3.2 times higher and that for $\mathrm{T}_{5}, 2.1-2.7$ times higher than that of $\mathrm{T}_{1}$.

\section{Discussion}

Erosion-induced soil and nutrient losses are major constraints to agricultural productivity in the sloping farm-lands. Use of cover crops and surface barriers such as contour hedgerow intercropping are cost effective technologies to minimize the erosion risk (Sudhishri et al., 2008; Lenka et al., 2012b; Tao et al., 2012; Biddoccu et al., 2016). Results presented herein indicate the erosion mitigation potential of weed cover management as compared to the traditional shifting cultivation (Tao et al., 2012; Gholami et al., 2013). The most visible impact in terms of reduced soil loss, plant root growth and crop yield was observed in the $T_{5}$ treatment with retention of weed biomass, live and subsequently the uprooted weed biomass put across the slope in the upstream side of the plant root. Retention of live and uprooted weed biomass, apart from reducing the runoff velocity, also filters sediments from runoff water (Lenka et al., 2012b; Cerdà et al., 2016). During the initial stage of maize growth, live weed biomass protected against rainfall erosivity on steep land and enhanced plant growth. Subsequently, at 20 DAS, weeds biomass was removed and retained on the surface as mulch. The retention of uprooted weed biomass provided surface cover, which coupled with the binding effect of maize roots, proved an effective barrier and led to the formation of stable terraces. Thus, soil erosion was significantly lower under $\mathrm{T}_{5}$ than that in other treatments for all runoff events in both years (Tables $2 \& 3$, Figs. $3 \& 4$ ). This trend is also evident from the average sediment concentration which was more than 4.0 times higher in $\mathrm{T}_{1}$ than that in $\mathrm{T}_{5}$ (Fig. 3). On sloping lands, therefore, selective weed retention can be a cost effective strategy for control of soil erosion and nutrient loss. Similar observations have also been reported for an olive (Olea europaea) grove established on land with slope gradient of $13 \%$, in which the highest runoff and soil loss were observed in the weed-free treatment (Gomez et al., 2009). In a long term runoff monitoring study in Italy, grass cover reduced runoff by at least $37 \%$ as compared to management by tillage. The sediment yield varied from 1.8 to $20.7 \mathrm{Mg} \mathrm{ha}^{-1} \mathrm{yr}^{-1}$ for grass cover and reduced tillage treatment, respectively (Biddoccu et al., 2016). The efficiency of surface mulch in controlling soil loss, runoff and phosphate loss has also been reported by Bakr et al. (2015), where the runoff loss as a percentage of the applied rainfall was reduced from $90 \%$ for the tilled plot to $28 \%$ in treatments having $10 \mathrm{~cm}$ compost/ mulch.

Research data on runoff and erosion have been reported for live vegetative barriers of different grass species and live contour hedgerow barriers of different shrub species (Gomez et al., 2009; Dass et al., 2011; Lenka et al., 2012b; Tao et al., 2012). For sloping land (12-46\% slope), Tao et al. (2012) reported reduction in runoff by 57\%, 94\% and $95 \%$ under contour hedgerow intercropping with maize + soybean, maize + alfalfa and maize + Hemerocallis citrina, as compared to maize only. Inclusion of grass filter strips enhanced the conservation effectiveness of hedge rows of Gliricidia in a high rainfall region of eastern India. In comparison with the control, these hedge rows reduced runoff and soil erosion by $30 \%$, while sequestering soil organic carbon at the rate of 0.35-1.35 Mg ha ${ }^{-1} \mathrm{yr}^{-1}$ (Lenka et al., 2012b). Conservation effectiveness of hedgerow barriers can be better than that of stone and soil dike terraces (Shen et al., 2010).

The alternate cover treatments also promoted better root growth 
and produced higher crop yield than that under $\mathrm{T}_{1}$ treatment (Table 5). On average, the root weight of maize under $T_{5}$ was 3.8 times higher and the RLD about 3 times higher than that under $\mathrm{T}_{1}$ in both years primarily because of lower soil erosion. The contrary effect is also possible. The better root growth environment in the $\mathrm{T}_{5}$ treatment due to weed and mulch cover in the inter-strip spaces might play a vital role in promoting soil aggregation and reducing erosion which led to formation of terraces (Tisdall and Oades, 1982; Gyssels et al., 2005). Because of the high runoff potential of the sloping lands as in the case of the experimental plot, the role of plant roots seems to be additive to the action of the vegetation cover (Gyssels et al., 2005). Lower root growth, poor crop yield and high sediment loss under $\mathrm{T}_{1}$ were also caused by loosening of soil during bunding (Fig. 5).

In addition to reducing soil erosion, mulching also enhances agronomic productivity (Aggarwal and Sharma, 2002). Mulching with weed biomass in conjunction with minimum tillage and strips of grass barrier reduced soil erosion and runoff by $51 \%$ and $45 \%$, respectively, on a gently sloping land in the Indian sub-Himalayas (Ghosh et al., 2015). Applying mulch at the rate of $4 \mathrm{Mg} \mathrm{ha}^{-1}$ decreased water runoff by $58 \%$, soil erosion by $72 \%$ and nutrient loss by $60 \%$ while also increasing the grain yield of maize (Kukal et al., 1993).

A judicious manipulation of weed cover controls soil erosion and nutrient loss (Francia et al., 2006), and leads to formation of phytogenic mounds (Abu-Zreig et al., 2004) by the barrier action and resulting deposition of sediments towards the upstream side of the strips of vegetative barriers (Zuazo and Pleguezuelo, 2008). In the present study, terrace formation across the slope was caused by the binding action of plant roots. Further, incorporation of weed biomass in soil in the vicinity of the plant rows enforced the action and thus resulted in the maximum formation of stable terraces under the $T_{5}$ treatment. Reduction in erosion is also due to increase in shear strength of the soil, which is a measure of the cohesiveness of soil particles and resistance of the soil mass to shearing forces exerted by forces of gravity, moving fluids and mechanical loads (Zuazo and Pleguezuelo, 2008). The binding action of plant roots in this study was reinforced by the live weed biomass and the weed mulch, which led to the formation of terraces and reduction of effective land slope in the $T_{5}$ treatment. The better plant growth reinforced shear strength of the soil- root matrix (Anderson and Richards, 1987), which was higher than the separate values of the soil or the roots (Simon and Collison, 2001; Zuazo and Pleguezuelo, 2008).

\section{Conclusion}

The data presented indicated the soil and nutrient losses were lower and maize yield higher under the cover management treatment with selective and controlled weed retention. A discriminative retention of weed cover also changed land slope gradient and formation of bioterraces. Of the cover management methods, selective weed retention is a cost-effective management strategy for conserving soil, water and plant nutrients on sloping lands of areas under shifting cultivation in the north-eastern region of India. Being a simple and low cost technology, it can be adopted by farmers of hilly regions of tropical and sub-tropical parts of the world experiencing similar soil erosion problems.

\section{Conflict of interest}

Authors declare no conflict of interest in the paper.

\section{Acknowledgement}

The financial support received from ICAR Research Complex for $\mathrm{NEH}$ region, Umiam, Meghalaya in taking up the study is thankfully acknowledged.

\section{References}

Abu-Zreig, M., Rudra, R.P., Lalonde, M.N., Whiteley, H.R., Kaushik, N.K., 2004 Experimental investigation of runoff reduction and sediment removal by vegetated filter strips. Hydrol. Processes. 18, 2029-2037. http://dx.doi.org/10.1002/hyp.1400.

Aggarwal, P., Sharma, N.K., 2002. Water uptake and yield of rainfed wheat in relation to tillage and mulch. Ind. J. Soil Conserv. 30, 155-160.

Anderson, M.G., Richards, K.S., 1987. Slope Stability; Geotechnical Engineering and Geomorphology. Wiley and Sons, Chichester, UK.

Bakr, N., Elbana, T.A., Arceneaux, A.E., Zhu, Y., Weindorf, D.C., Selim, H.M., 2015. Runoff and water quality from highway hillsides: influence of compost/mulch. Soil Tillage Res. 150, 158-170.

Biddoccu, M., Ferraris, S., Opsi, F., Cavallo, E., 2016. Long term monitoring of soil management effects on runoff and soil erosion in sloping vineyards in Alto Monferrato. Soil Tillage Res. 155, 176-189.

Cerdà, A., González-Pelayo, Ó., Giménez-Morera, A., Jordán, A., Pereira, P., Novara, A., Brevik, E.C., Prosdocimi, M., Mahmoodabadi, M., Keesstra, S., García Orenes, F., Ritsema, C.J., 2016. The use of barley straw residues to avoid high erosion and runoff rates on persimmon plantations in Eastern Spain under low frequency - high magnitude simulated rainfall events. Soil Res. 54, 154-165. http://dx.doi.org/10. 1071/SR15092.

Das, A., Ghosh, P.K., Choudhury, B.U., Patel, D.P., Munda, G.C., Ngachan, S.V., Chowdhury, P., 2009. Climate change in Northeast India: recent facts and events -worry for agricultural management. ISPRS Archives XXXVIII-8/W3 Workshop Proceedings: Impact of Climate Change on Agriculture 32-37.

Das, A., Ghosh, P.K., Lal, R., Saha, R., Ngachan, S.V., 2014. Soil quality effect of conservation practices in maize-rapeseed cropping system in eastern Himalaya. Land Degrad. Dev. http://dx.doi.org/10.1002/ldr.2325.

Dass, A., Sudhishri, S., Lenka, N.K., Patnaik, U.S., 2011. Runoff capture through vegetative barriers and planting methodologies to reduce erosion and improve soil moisture, fertility and crop productivity in southern Orissa, India. Nutr. Cycl. Agroecosyst. 89, 45-57. http://dx.doi.org/10.1007/s10705-010-9375-3.

Francia, J.R., Durán, Z.V.H., Martinez, R.A., 2006. Environmental impact from mountainous olive orchards under different soil-management systems (SE Spain). Sci. Total Environ. 358, 46-60. http://dx.doi.org/10.1016/j.scitotenv.2005.05.036.

Gessesse, B., Bewket, W., Bräuning, A., 2015. Model-based characterization and monitoring of runoff and soil erosion in response to land use/land cover changes in the modjo watershed, Ethiopia. Land Degrad. Dev. 26, 711-724. http://dx.doi.org/ 10.1002/ldr.2276.

Gholami, L., Sadeghi, S.H., Homaee, M., 2013. Straw mulching effects on splash erosion, runoff and sediment yield from eroded plots. Soil Sci. Soc. Am. J. 77, 268-278. http://dx.doi.org/10.2136/sssaj2012.0271.

Ghosh, B.N., Dogra, P., Sharma, N.K., Bhattacharyya, R., Mishra, P.K., 2015. Conservation agriculture impact for soil conservation in maize-wheat cropping system in the Indian sub-Himalayas. Int. Soil Water Conserv. Res. 3, 112-118. http://dx.doi.org/10.1016/ j.iswcr.2015.05.001.

Gomez, J.A., Sobrinho, T.A., Giraldez, J.V., Fereres, E., 2009. Soil management effects on runoff, erosion and soil properties in an olive grove of Southern Spain. Soil Tillage Res. 102, 5-13. http://dx.doi.org/10.1016/j.still.2008.05.005.

Gyssels, G., Poesen, J., Bochet, E., Li, Y., 2005. Impact of plant roots on the resistance of soil to erosion by water: a review. Prog. Phys. Geogr. 29, 189-217.

Jackson, M.L., 1973. Soil Chemical Analysis. Prentice Hall of India Pyt. Ltd., New Delhi.

Keesstra, S., Pereira, P., Novara, A., Brevik, E.C., Azorin-Molina, C., Parras-Alcántara, L., Jordán, A., Cerdà, A., 2016. Effects of soil management techniques on soil water erosion in apricot orchards. Sci. Total Environ. 551-552, 357-366. http://dx.doi.org/ 10.1016/j.scitotenv.2016.01.182.

Kukal, S.S., Khera, K.L., Hadda, M.S., 1993. Soil erosion management on arable lands of submontane Punjab, India: a review. Arid Soil Res. Rehabil. 7, 369-375.

Kuotsu, K., Das, A., Lal, R., Munda, G.C., Ghosh, P.K., Ngachan, S.V., 2014. Land forming and tillage effects on soil properties and productivity of rainfed groundnut (Arachis hypogaea L.)-rapeseed (Brassica campestris L.) cropping system in north-eastern India. Soil Tillage Res. 142, 15-24. http://dx.doi.org/10.1016/j.still.2014.04.008.

Lal, R., 2001. Managing world soils for food security and environmental quality. Adv. Agron. 74, 155-192. http://dx.doi.org/10.1016/S0065-2113(01)74033-3.

Lenka, N.K., Choudhury, P.R., Sudhishri, S., Das, A., Patnaik, U.S., 2012a. Soil aggregation, carbon build up and root zone soil moisture in degraded sloping lands under selected agroforestry based rehabilitation systems in eastern India. Agric. Ecosyst. Environ. 150, 54-62. http://dx.doi.org/10.1016/j.agee.2012.01.003.

Lenka, N.K., Das, A., Sudhishri, S., Patnaik, U.S., 2012b. Soil carbon sequestration and erosion control potential of hedgerows and grass filter strips in sloping agricultural lands of eastern India. Agric. Ecosyst. Environ. 158, 31-40. http://dx.doi.org/10. 1016/j.agee.2012.05.017.

Nath, A.J., Brahma, B., Lal, R., Das, A.K., 2016. Soil and jhum cultivation. Encyclopaedia of soil science. SAS/STAT ${ }^{\circledR} 12.3$ User's Guide, third edition. SAS Institute Inc., Cary, NChttp://dx.doi.org/10.1081/E-ESS3-120053748.

Satapathy, K.K., 1996. Shifting cultivation in north eastern region: an overview. J. Soil Water Conserv. 34, 171-179.

Sharma, U.C., Prasad, R., 1995. Socio-economic aspects of acid soil management and alternate land use systems for north-eastern states of India. In: Date, R.A., Grundon, N.J., Rayment, G.E., Probert, M.E. (Eds.), Plant-Soil Interactions at Low pH: Principles and Management. Kluwer Academic Press, The Netherlands, pp. 689-696.

Sharma, U.C., Sharma, V., 2005. Traditional wisdom of tribal people in integrated water resources management and environmental quality. In: Takara, K., Tachkawa, Y., Nawrathna, N.M.N.S.B. (Eds.), Monitoring, Prediction and Mitigation of Water Related Disasters. DPRI, Kyoto University, pp. 709-712. 
Sharma, U.C., Datta, M., Sharma, V., 2014. Soil fertility erosion, runoff and crop productivity affected by different farming systems. Ecopersia 2, 629-650.

Shen, Z., Gong, Y., Li, Y., Liu, R., 2010. Analysis and modeling of soil conservation measures in the Three Gorges Reservoir Area in China. Catena 81, 104-112. http:// dx.doi.org/10.1016/j.catena.2010.01.009.

Simon, A., Collison, A., 2001. Scientific basis for stream-bank stabilization using riparian vegetation. In: Proceedings of the 7th Federal Interagency Sedimentation Conference. March 25-29, 2001, Reno, Nevada, USA. .

Singh, A., Singh, M.D., 1978. Effect of various stages of shifting cultivation on soil erosion from steep hill slopes. Indian For. 106, 115-121.

Singh, R.K., Panda, R.K., Satapathy, K.K., Ngachan, S.V., 2012. Runoff and sediment yield modelling for a treated hilly watershed in eastern himalaya using the water erosion prediction project model. Water Resour. Manage. 26, 643-665. http://dx.doi.org/10. 1007/s11269-011-9937-4.
Sudhishri, S., Das, A., Lenka, N.K., 2008. Efficacy of vegetative barriers for rehabilitation of degraded hill slopes in eastern India. Soil Tillage Res. 99, 98-107. http://dx.doi. org/10.1016/j.still.2008.01.004.

Tao, W., Bo, Z., Lizhong, X., 2012. Effects of contour hedgerow intercropping on nutrient losses from the sloping farmland in the Three Gorges Area. China J. Mt. Sci. 9, 105-114. http://dx.doi.org/10.1007/s11629-012-2197-9.

Tisdall, J.M., Oades, J.M., 1982. Organic matter and water stable aggregates in soils. J. Soil Sci. 33, 141-163.

Velayutham, M., 1999. Soil resources of India - potential problems and strategies for the future. In: Lead Paper: National Seminar on Strategies for Agricultural Research in North East. November 10-12, 1999, Umiam, Meghalaya, India. .

Zuazo, V.H.D., Pleguezuelo, C.R.R., 2008. Soil-erosion and runoff prevention by plant covers - a review. Agron. Sustain. Dev. 28, 65-86. http://dx.doi.org/10.1051/ agro:2007062. 